\title{
Gastrointestinal nematode infections in sheep raised in Botucatu, state of São Paulo, Brazil
}

Infecções por nematódeos gastrintestinais em ovinos criados em Botucatu, estado de São Paulo, Brasil

Maurício Orlando Wilmsen¹; Bruna Fernanda Silva²; César Cristiano Bassetto; Alessandro Francisco Talamini do Amarante ${ }^{1 *}$

${ }^{1}$ Departamento de Parasitologia, Instituto de Biociências, Universidade Estadual Paulista - UNESP, Botucatu, SP, Brasil

${ }^{2}$ Universidade do Planalto Catarinense - UNIPLAC, Lages, SC, Brasil

Received April 24, 2014

Accepted June 25, 2014

\begin{abstract}
Gastrointestinal nematode infections were evaluated in sheep raised in Botucatu, state of São Paulo, Brazil between April 2008 and March 2011. Every month, two tracer lambs grazing with a flock of sheep were exposed to natural infection with gastrointestinal nematodes for 28 consecutive days. At the end of this period, the lambs were sacrificed for worm counts. Haemonchus contortus presented $100 \%$ of prevalence. The seasons exerted no significant influence on the mean intensity of $H$. contortus, which ranged from 315 worms in November 2010 to 2,5205 worms in January 2011. The prevalence of Trichostrongylus colubriformis was also 100\%, with the lowest mean intensity (15 worms) recorded in February 2011 and the highest (9,760 worms) in October 2009. In the case of T. colubriformis, a significant correlation coefficient was found between worm counts vs. rainfall $(r=-0.32 ; \mathrm{P}<0.05)$. Three other nematodes species were found in tracer lambs, albeit in small numbers. Their prevalence and mean intensity (in parenthesis) were as follows: Oesophagostomum columbianum 28\% (25.2), Cooperia curticei 7\% (4.5) and Trichuris spp. 2\% (1). In conclusion, the environmental conditions of the area proved to be highly favorable for the year-round transmission of H. contortus and T. colubriformis.
\end{abstract}

Keywords: Haemonchus contortus, Trichostrongylus colubriformis, tracer lamb, nematode burden, seasonal variation.

\section{Resumo}

A ocorrência de infecçôes por nematódeos gastrintestinais foi avaliada de abril de 2008 até março de $2011 \mathrm{em}$ ovinos criados em Botucatu, estado de São Paulo. Todos os meses, dois cordeiros traçadores foram expostos à infecção natural por nematódeos gastrintestinais, durante 28 dias consecutivos, ao pastejar junto com um rebanho de ovelhas. Ao final desse período, os animais foram sacrificados para a identificação e quantificação dos helmintos. Haemonchus contortus apresentou prevalência de $100 \%$. Não houve influência significativa das estaçôes do ano na intensidade média de $H$. contortus, que variou de 315 vermes em novembro/2010 a 25.205 vermes em janeiro/2011. Trichostrongylus colubriformis também apresentou prevalência de 100\% com a menor intensidade média (15 vermes) em fevereiro/2011 e a maior (9.760 vermes) em outubro/2009. No caso de T. colubriformis, houve correlaçáo significativa entre as contagens de vermes x precipitação $(r=-0,32 ; \mathrm{P}<0,05)$. Outras três espécies de nematódeos foram encontradas nos cordeiros traçadores, no entanto em pequenas quantidades, com as seguintes prevalências e intensidades médias (entre parênteses): Oesophagostomum columbianum 28\% (25,2), Cooperia curticei 7\% (4,5) e Trichuris spp. $2 \%$ (1). Em conclusão, as condiçôes ambientais da área foram muito favoráveis durante todo o ano para a transmissão de H. contortus e T. colubriformis.

Palavras-chave: Haemonchus contortus, Trichostrongylus colubriformis, cordeiro traçador, carga parasitária, variação sazonal.

\footnotetext{
*Corresponding author: Alessandro Francisco Talamini do Amarante

Departamento de Parasitologia, Instituto de Biociências, Universidade Estadual

Paulista - UNESP, CEP 18618-970, Botucatu, SP, Brasil

e-mail: amarante@ibb.unesp.br
} 


\section{Introduction}

Gastrointestinal nematode infections are the major constraint to sheep production worldwide. The distribution of different nematode species and the risk of massive infections are greatly influenced by environmental conditions. For instance, Teladorsagia circumcincta is an important parasite of sheep in locations with long cold winters (MEDEROS et al., 2010), while its presence is not observed in sheep raised in regions with higher temperatures, where other species, particularly Haemonchus contortus and Trichostrongylus colubriformis, predominate among the parasitic fauna (AMARANTE et al., 2004; SILVA et al., 2012a). The occurrence of $H$. contortus, however, is not restricted only to high temperature regions, for it has been reported in sheep flocks raised even at latitudes near the polar circle (LINDQVIST et al., 2001). H. contortus demonstrates an impressive capacity to adapt and survive in adverse environmental conditions. It has been demonstrated that the worm population can survive inside the host for more than a year, producing fertile eggs that ensure its preservation in a flock (SANTOS et al., 2014).

Several factors influence the epidemiology of parasitic diseases. The degree of environmental contamination by the free living stages of nematodes is greatly influenced by the interaction between two major factors: first, the presence of susceptible animals shedding large numbers of eggs in feces, and second, environmental conditions suitable for the development and survival of the free living stages of nematodes. Other factors are also important, such as the number of animals per area and the frequency and efficacy of anthelmintic treatments.

In this study, gastrointestinal nematode infections in sheep were evaluated monthly from April 2008 to March 2011 in Botucatu, state of São Paulo, in a region with a humid subtropical climate characterized by warm and wet conditions in summer and low rainfall and mild temperatures in winter.

\section{Materials and Methods}

\section{Study location}

The experiment, which was approved by the Ethics Committee for Animal Research of UNESP - 86/07 - CEEA, was conducted on a sheep farm belonging to the São Paulo State University - UNESP, located at $22^{\circ} 82^{\prime}$ latitude South and $48^{\circ} 41^{\prime}$ longitude West, at an altitude of $613 \mathrm{~m}$ a.s.l., in Botucatu, state of São Paulo, Brazil. The climate type is Cwa, according to the Köppen classification, and the data on average temperature, relative air humidity and rainfall during the period of this study were obtained from the Department of Environmental Sciences, College of Agricultural Sciences, UNESP (Table 1).

\section{Management of tracer lambs}

The animals used in this experiment were the same as those used in a previously published study about Oestrus ovis epidemiology (SILVA et al., 2012b). Briefly, during the 36 months of observations,
72 Ile de France weathered male lambs less than a year old were used. The tracer animals, which were purchased from a commercial sheep farm, were naturally infected with gastrointestinal nematodes upon their arrival at the University facilities. For this reason, they were housed and orally drenched once a day for three consecutive days with levamisole phosphate $\left(10 \mathrm{mg} / \mathrm{kg}\right.$, Ripercol ${ }^{\circledR} \mathrm{L} 150 \mathrm{~F}$, Fort Dodge) and albendazole $\left(10 \mathrm{mg} / \mathrm{kg}\right.$, Valbazen ${ }^{\circledR} 10$ Cobalt, Pfizer). A week later, the same protocol was carried out with trichlorfon $\left(100 \mathrm{mg} / \mathrm{kg}\right.$, Neguvon ${ }^{\circledR}$, Bayer S.A.) to eliminate any remaining gastrointestinal nematode infection. A series of fecal examinations were performed to confirm the elimination of infection by nematodes. While indoors, the animals were fed with an amount of concentrate (Tech Ovin Unique, Socil ${ }^{\circledR}$ ) corresponding to $1 \%$ of their mean live weight and were given free access to Tifton hay and tap water.

Every month from April 2008 to March 2011, two tracer lambs were exposed to natural infection with gastrointestinal nematodes for 28 consecutive days, while grazing with a sheep flock. The sheep farm where the tracer lambs were placed had 156 Bergamasca sheep when the study began and 202 animals when it ended. The adult ewes were kept permanently in rotational grazing on Panicum maximum cv Tanzania grass on an area of 8 hectares. Lambing occurred in winter and, after weaning at two months of age, the young animals were kept indoors until they were over one year old. This procedure was adopted on the farm to prevent the mortality of young animals due to haemonchosis. Due to the low amount of forage during winter and early spring (from June to October), the animals received additional corn silage feed daily.

On the day the tracer animals were placed with the flock, fecal samples were collected randomly from 20 ewes on the farm. Each sample was subjected to nematode fecal egg counts (FEC) and a composite fecal culture was prepared for the production of infective larvae, which were classified to the level of genus, as described by Ueno and Gonçalves (1998).

Animals of the flock were subjected to selective anthelmintic treatment based on FEC, which was performed by the people responsible for worm control on the farm. During the study, the authors of this paper did not interfere in this worm control procedure.

\section{Worm counts}

After grazing with a sheep flock for 28 consecutive days, two tracer lambs were sacrificed monthly for worm counts. The abomasum was opened along its greater curvature and the contents placed in a container. An aliquot of $10 \%$ of the abomasal contents was preserved in 5\% formalin. The mucosal layers of all the abomasa were soaked in saline solution at $38^{\circ} \mathrm{C}$ for $6 \mathrm{~h}$. The entire content of digested material was collected and preserved in 5\% formalin. A similar procedure was employed to process the small intestine, from which an aliquot of $10 \%$ of digested material was collected. The large intestine was opened and an aliquot of $10 \%$ of the contents was collected and preserved. Worm identification and counting procedures were performed on the preserved material, as described by Ueno and Gonçalves (1998). The identification of Cooperia and Trichostrongylus down 
Table 1. Monthly rainfall and averages of temperature and relative air humidity from April 2008 to March 2011.

\begin{tabular}{|c|c|c|c|c|}
\hline Month /Year & Rainfall (mm) & $\begin{array}{c}\text { Maximum temperature } \\
\left({ }^{\circ} \mathrm{C}\right)\end{array}$ & $\begin{array}{c}\text { Minimum temperature } \\
\left({ }^{\circ} \mathrm{C}\right)\end{array}$ & $\begin{array}{c}\text { Relative air humidity } \\
(\%)\end{array}$ \\
\hline April/2008 & 102.8 & 25.6 & 17.4 & 68 \\
\hline May & 115.7 & 22.8 & 13.8 & 54.7 \\
\hline June & 30.8 & 24.5 & 13.5 & 60 \\
\hline July & 0 & 24.6 & 13.8 & 40.5 \\
\hline August & 104.1 & 25.5 & 15.1 & 53.3 \\
\hline September & 29.9 & 25.5 & 15.1 & 63.4 \\
\hline October & 153.8 & 26.8 & 18.2 & 72.1 \\
\hline November & 69.3 & 27.3 & 16.6 & 73.2 \\
\hline December & 136.5 & 28.4 & 17.1 & 70.5 \\
\hline January 2009 & 331.6 & 26.6 & 18.2 & 84.4 \\
\hline February & 141.6 & 28.4 & 19.5 & 78.3 \\
\hline March & 111.5 & 28.8 & 19.2 & 73.9 \\
\hline April & 86.8 & 26.7 & 16.5 & 72.5 \\
\hline May & 62.7 & 24.9 & 15.0 & 73.9 \\
\hline June & 102.7 & 20.8 & 11.3 & 73.2 \\
\hline July & 143.8 & 22.6 & 13.0 & 79.6 \\
\hline August & 89.1 & 24.1 & 13.7 & 67.6 \\
\hline September & 150.5 & 25.5 & 15.8 & 76.1 \\
\hline October & 141.8 & 26.7 & 15.1 & 77.6 \\
\hline November & 289 & 29.5 & 19.8 & 76.1 \\
\hline December & 327.1 & 26.9 & 19.1 & 81.2 \\
\hline January 2010 & 350.5 & 27.5 & 19.5 & 69.7 \\
\hline February & 134.6 & 29.4 & 20.1 & 53.6 \\
\hline March & 134.6 & 28.4 & 18.7 & 57.3 \\
\hline April & 71.7 & 26.4 & 17.1 & 56.4 \\
\hline May & 39.5 & 24.4 & 14.1 & 46.3 \\
\hline June & 22.8 & 25.5 & 12.4 & 48.2 \\
\hline July & 55.3 & 26.3 & 13.7 & 39.8 \\
\hline August & 0 & 27.6 & 12.3 & 49.5 \\
\hline September & 63.1 & 27.6 & 13.6 & 52.1 \\
\hline October & 56.1 & 27.7 & 13.4 & 48.2 \\
\hline November & 139.4 & 28.4 & 16.3 & 56.1 \\
\hline December & 243.2 & 28.7 & 18.3 & 78 \\
\hline January 2011 & 712.3 & 29.6 & 19.6 & 85 \\
\hline February & 189.6 & 29.8 & 19.4 & 77 \\
\hline March & 162 & 25.8 & 18.3 & 78 \\
\hline
\end{tabular}

Source: Department of Environmental Sciences, College of Agricultural Sciences, São Paulo State University - UNESP, Botucatu, SP, Brazil.

to species level was based on the morphology of spicules of male specimens (UENO; GONÇALVES, 1998).

In addition, the presence and number of longitudinal ridges (synlophe) was evaluated at the esophageal-intestinal junction, at the mid-body and 1-2 mm after the mid-body of 10 male and 10 female Haemonchus specimens obtained from each animal, to properly determine the Haemonchus species present (LICHTENFELS et al., 1994). Worm processing for synlophe analysis, as well as determination of the number of ridges, were performed according to Silva et al. (2014).

\section{Statistical analyses}

An analysis of variance was performed to compare the degree of infection throughout the year. Data were transformed using $\log 10(x+1)$ prior to analysis and grouped according to the season of the year: autumn (March-April-May), winter (June-JulyAugust), spring (September-October-November) and summer (December-January-February). Significant differences between season means were determined by Tukey's test at 5\%. Spearman's rank correlation coefficients between worm burden and climatic variables (temperature, rainfall and air relative humidity) were estimated. All the analyses were performed using SAS version 9.2.

Descriptive statistical analyses were used to summarize the data, as proposed by Bush et al. (1997), using the following terms:

Prevalence: the number of hosts infected with each nematode species divided by the number of hosts examined;

Intensity (of infection): the number of each nematode species in a single infected host;

Mean intensity: the total number of each nematode species found divided by the number of hosts infected with that parasite. 


\section{Results}

The mean intensity of $H$. contortus ranged from 315 worms in November 2010 to 25,205 worms in January 2011 (Figure 1). In other words, $H$. contortus presented $100 \%$ of prevalence. There was no significant influence of the seasons on the mean intensity of $H$. contortus (Table 2). No significant correlation coefficients were recorded between $H$. contortus worm counts and climatic variables. T. colubriformis also presented $100 \%$ prevalence, with the lowest worm burdens during the summer months (Figure 1; Table 2). In the case of T. colubriformis, the lowest mean intensity (15 worms) was recorded in February 2011 and the highest (9,760 worms) in October 2009. The only significant correlation coefficient was recorded between $T$. colubriformis worm counts vs. precipitation $(r=-0.32 ; \mathrm{P}<0.05)$.

Three other nematode species were found in the tracer lambs, albeit in small numbers. Their prevalence and mean intensity (in parenthesis) were as follows: Oesophagostomum columbianum 28\% (25.2), Cooperia curticei 7\% (4.5) and Trichuris spp. 2\% (1).

Each month, fecal samples were collected randomly from 20 ewes on the farm. The FEC values showed the typical aggregate distribution, with most of the sheep showing low FEC and a few with high FEC. In 29 of the 36 months of sampling, medians of FEC were lower than 1000 eggs per gram (EPG). However, several animals shed large number of eggs in feces, with values exceeding 5000 EPG on 32 occasions, and one ewe showing a maximum of 55,200 EPG in December 2009 (Table 3). Haemonchus and Trichostrongylus infective larvae presented an overall average of $93.1 \%$ and $6.5 \%$, respectively, in fecal cultures from ewes. A few Oesophagostomum larvae were also detected on five occasions, with a maximum of 8\% in July 2010 (Table 3).

The synlophe analysis confirmed only the presence of $H$. contortus infecting the experimental sheep, with no evidence of the presence of Haemonchus placei.

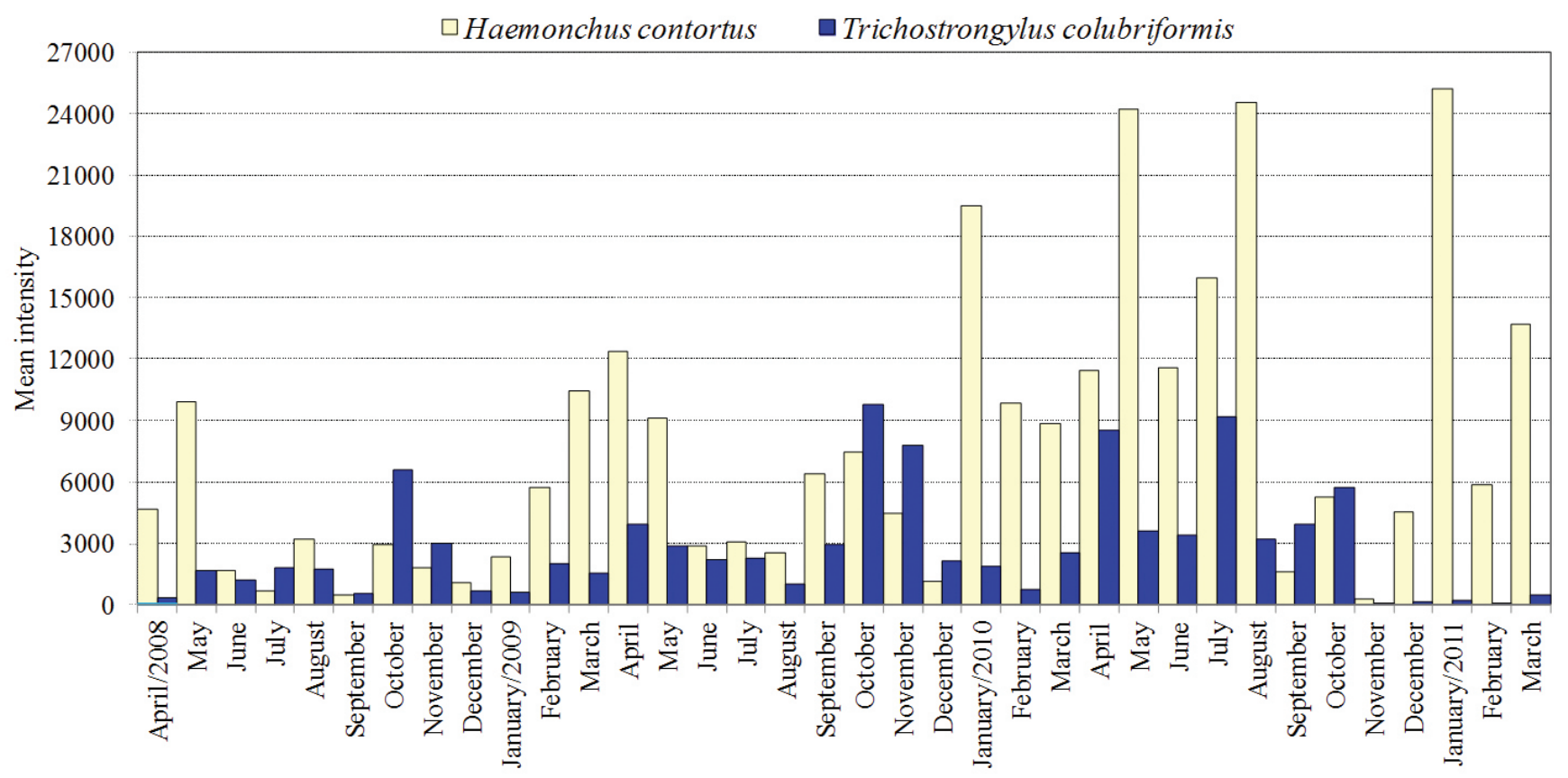

Figure 1. Mean intensity of Haemonchus contortus and Trichostrongylus colubriformis in tracer sheep from April 2008 to March 2011 , in Botucatu, state of São Paulo, Brazil.

Table 2. Mean intensity and prevalence of Haemonchus contortus and Trichostrongylus colubriformis in tracer lambs that grazed on a contaminated pasture during 28 days in Botucatu, state of São Paulo, Brazil. Two lambs were evaluated per month from April 2008 to March 2011 (18 per season, with a total of 72 animals).

\begin{tabular}{clllll}
\hline \multicolumn{1}{c}{ Species } & Stage of development & \multicolumn{1}{c}{ Autumn } & \multicolumn{1}{c}{ Winter } & \multicolumn{1}{c}{ Spring } & \multicolumn{1}{c}{ Summer } \\
\hline H. contortus & Early L4 & $1834(0-11691)$ & $3448(0-21260)$ & $550(0-5581)$ & $568(0-3050)$ \\
& Late L4 & $888(0-2590)$ & $438(0-2480)$ & $513(0-5332)$ & $1049(0-8640)$ \\
& Early L5 & $400(0-3320)$ & $108(0-540)$ & $786(0-9619)$ & $450(0-2940)$ \\
& Late L5 and adults & $6487(333-15760)$ & $3316(186-12000)$ & $4258(40-12399)$ & $5683(5-18305)$ \\
& Total burden & $9614(4392-19186)$ & $7316(186-30350)$ & $6109(123-32942)$ & $7755(68-30421)$ \\
& Prevalence & $100 \%$ & $100 \%$ & $100 \%$ & $100 \%$ \\
T. colubriformis & Total burden & $2448 \mathrm{ab}(10-9180)$ & $2936 \mathrm{a}(395-15830)$ & $4830 \mathrm{a}(70-12840)$ & $956 \mathrm{~b}(10-2620)$ \\
& Prevalence & $100 \%$ & $100 \%$ & $100 \%$ & $100 \%$ \\
\hline
\end{tabular}

Arithmetic means with different letters in row are significantly different. Minimum and maximum values are in parenthesis. L: larvae. 
Table 3. Median (range in parenthesis) of nematode fecal egg counts (FEC) and third stage larvae in fecal cultures from samples collected randomly from 20 ewes on the experimental sheep farm.

\begin{tabular}{|c|c|c|c|c|}
\hline \multirow{2}{*}{ Month /Year } & \multirow{2}{*}{ FEC } & \multicolumn{3}{|c|}{ Third stage larvae (\%) } \\
\hline & & H. contortus & T. colubriformis & O. columbianum \\
\hline April/2008 & $700(0-11000)$ & 94 & 6 & 0 \\
\hline May & $1100(0-38100)$ & 100 & 0 & 0 \\
\hline June & $350(0-6500)$ & 91 & 9 & 0 \\
\hline July & $2000(0-26400)$ & 96 & 4 & 0 \\
\hline August & $2300(0-34000)$ & 90 & 10 & 0 \\
\hline September & $800(0-8300)$ & 96 & 4 & 0 \\
\hline October & $400(0-15600)$ & 95 & 5 & 0 \\
\hline November & $150(0-9000)$ & 74 & 26 & 0 \\
\hline December & $100(0-8500)$ & 100 & 0 & 0 \\
\hline January 2009 & $1400(0-22400)$ & 99 & 1 & 0 \\
\hline February & $250(0-22600)$ & 93 & 7 & 0 \\
\hline March & $950(0-7500)$ & 96 & 4 & 0 \\
\hline April & $550(0-11400)$ & 95 & 5 & 0 \\
\hline May & $100(0-2200)$ & 91 & 9 & 0 \\
\hline June & $800(0-20100)$ & 93 & 7 & 0 \\
\hline July & $950(0-45700)$ & 98 & 2 & 0 \\
\hline August & $800(0-4300)$ & 96 & 4 & 0 \\
\hline September & $0(0-9900)$ & 86 & 14 & 0 \\
\hline October & $100(0-17000)$ & 93 & 7 & 0 \\
\hline November & $0(0-9800)$ & 95 & 5 & 0 \\
\hline December & $100(0-55200)$ & 81 & 18 & 1 \\
\hline January 2010 & $100(0-7100)$ & 99 & 1 & 0 \\
\hline February & $300(0-5900)$ & 94 & 4 & 2 \\
\hline March & $800(0-27300)$ & 100 & 0 & 0 \\
\hline April & $350(0-69100)$ & 96 & 4 & 0 \\
\hline May & $550(0-18800)$ & 76 & 22 & 2 \\
\hline June & $550(0-31900)$ & 97 & 3 & 0 \\
\hline July & $550(0-8800)$ & 72 & 20 & 8 \\
\hline August & $0(0-1300)$ & 87 & 13 & 0 \\
\hline September & $0(0-5800)$ & 95 & 5 & 0 \\
\hline October & $1950(0-7400)$ & 100 & 0 & 0 \\
\hline November & $300(0-3900)$ & 96 & 4 & 0 \\
\hline December & $2150(0-25300)$ & 97 & 1 & 2 \\
\hline January 2011 & $100(0-7400)$ & 98 & 2 & 0 \\
\hline February & $200(0-12700)$ & 98 & 2 & 0 \\
\hline March & $1700(0-9600)$ & 93 & 7 & 0 \\
\hline
\end{tabular}

\section{Discussion}

During this trial, the researchers did not interfere in the protocol of anthelmintic treatments that has been adopted for several years by the people responsible for worm control of the sheep flock where the tracer lambs were placed monthly. However, we were aware of the severe anthelmintic resistance was on that farm. In a study conducted in the late 80s, ivermectin, oxfendazole and levamisole showed very poor efficacy in that flock (AMARANTE et al., 1992). Later, moxidectin and closantel were used intensively, but also resulted in anthelmintic resistance (information not published). Therefore, we can assume that the protocol of anthelmintic treatments employed during the trial had a very limited effect (possibly none) on the epidemiology of $H$. contortus and T. colubriformis, the major parasites detected in this study.

With regard to H. contortus epidemiology, a "Haemonchus season" is usually observed in Brazil's most important sheep production regions, such as the south. This season occurs especially during warm moist summer months, with a reduction in the prevalence of H. contortus during cold winter months (SANTIAGO et al., 1976; RAMOS et al., 2004). In contrast, in regions with year round high temperatures, the limiting factor for $H$. contortus transmission is the lack of moisture during prolonged periods of drought, such as those observed in Brazil's semiarid northeast (CHARLES, 1995; SOUZA et al., 2013). This seasonal trend in the prevalence and/ or intensity of infection was not observed in our experimental conditions, in which $H$. contortus transmission, with high worm 
burdens, occurred year round. These observations are consistent with those of other studies conducted in the same area, which demonstrated the year-round presence of $H$. contortus third stage larvae on pastures grazed by sheep (AMARANTE; BARBOSA, 1995; CARNEIRO; AMARANTE, 2008).

In the region of this trial, occasional rainfall occurs during the so-called "dry season." For instance, during the 36 months of the trial, no rainfall was recorded only in two months, July 2009 and August 2010. Coincidentally, in August 2010, tracer lambs acquired a massive worm infection, with an average of more than $24,000 H$. contortus specimens. This finding clearly indicates that the free living stages of $H$. contortus were able to survive during the winter, despite the absence of rains. Although first and second stage larvae are considered highly vulnerable to desiccation, once their development to the L3 stage is complete, all the major trichostrongylidae species are considerably less susceptible to unfavorable climate conditions (O'CONNOR et al., 2007). It has been reported that, in the laboratory and in the field, infective larvae are able to survive several cycles of desiccation/ rehydration, in a process called anhydrobiosis, in which metabolic activity is decreased and larval survival is extended (LETTINI; SUKHEDEO, 2006).

Trichostrongylus colubriformis was the second most important parasite. T. colubriformis presented a lower worm burden than $H$. contortus in most of the months of this trial. In part, this was because the permanent sheep of the flock shed on average 14.3 times more Haemonchus eggs than Trichostrongylus eggs, based on the FEC and on the identification of third stage larvae from cultures. However, on average, the tracer lambs presented only 2.76 times more $H$. contortus (overall mean of 7,694 specimens) than T. colubriformis (overall mean of 2,792 specimens). Therefore, we can infer that, in fact, the free living stages of $T$. colubriformis presented a higher rate of development and survival than $H$. contortus in the environment. There are indications that the free-living stages of $T$. colubriformis are more tolerant to dry conditions and low temperatures than $H$. contortus (reviewed by O'CONNOR et al., 2006).

Trichostrongylus colubriformis showed averages exceeding 4,000 specimens on six occasions (October 2008, 2009 and 2010; November 2009; April and July 2010). This draws attention to the high mean intensity of infection that always occurs in October. During the trial, the average temperatures in October varied from 20.6 to $22.5^{\circ} \mathrm{C}$ and the rainfall ranged from 56.1 to $153.8 \mathrm{~mm}$, i.e., there was association of mild temperatures with moderate rainfalls. These are possibly the best environmental conditions for the transmission of T. colubriformis. In contrast, high temperatures associated with heavy rainfalls that occurred during summer caused a decline in T. colubriformis transmission.

In conclusion, the results of this trial indicate that the environmental conditions of this region are extremely favorable for the year-round transmission of $H$. contortus and T. colubriformis.

\section{Acknowledgments}

The authors are indebted to Mr. Valdir A. Paniguel, Mr. Moises dos Santos and Mr. Edvaldo J. Vito for their technical assistance. This study was funded by FAPESP (São Paulo Research
Foundation) under Grant No. 2008/53494-2. Bruna F. Silva and César C. Bassetto received financial support from FAPESP (Grant Nos. 2007/58244-1 and 2009/03504-4), and Maurício O. Wilsen and Alessandro F. T. Amarante received support from $\mathrm{CNPq}$ (National Council for Scientific and Technological Development).

\section{References}

Amarante AFT, Barbosa MA, Oliveira MAG, Carmello MJ, Padovani CR. Efeito da administração de oxfendazol, ivermectina e levamisol sobre os exames coproparasitológicos de ovinos. BrazJ Vet Res Anim Sci 1992; 29(1): 31-38.

Amarante AFT, Barbosa MA. Seasonal variations in populations of infective larvae on pasture and nematode faecal egg output in sheep. Vet Zootec 1995; 7(1): 127-133

Amarante AFT, Bricarello PA, Rocha RA, Gennari SM. Resistance of Santa Ines, Suffolk and Ile de France sheep to naturally acquired gastrointestinal nematode infections. Vet Parasitol 2004; 120(1-2): 91106. PMid:15019147. http://dx.doi.org/10.1016/j.vetpar.2003.12.004

Bush AO, Lafferty KD, Lotz JM, Shostak AW. Parasitology meets ecology on its own terms: Margolis et al. revisited. J Parasitol 1997; 83(4): 575583. PMid:9267395. http://dx.doi.org/10.2307/3284227

Carneiro RDC, Amarante AFT. Seasonal effect of three pasture plants species on the free-living stages of Haemonchus contortus. Arq Bras Med Vet Zootec 2008; 60(4): 864-872. http://dx.doi.org/10.1590/S010209352008000400014

Charles TP. Disponibilidade de larvas infectantes de nematódeos gastrintestinais parasitas de ovinos deslanados no semi-árido pernambucano. Ciênc Rural 1995; 25(3): 437-442. http://dx.doi. org/10.1590/S0103-84781995000300019

Lettini SE, Sukhedeo VK. Anhydrobiosis increases survival of trichostrongyle nematodes. J Parasitol 2006; 92(5): 1002-1009. PMid:17152941. http://dx.doi.org/10.1645/GE-784R.1

Lichtenfels JR, Pilitt PA, Hoberg EP. New morphological characters for identifying individual specimens of Haemonchus spp. (Nematoda: Trichostrongyloidea) and a key to species in ruminants of North America. J Parasitol 1994; 80(1): 107-119. PMid:8308643. http://dx.doi. org/10.2307/3283353

Lindqvist Å, Ljungström B-L, Nilsson O, Waller PJ. The dynamics, prevalence and impact of nematode infections in organically raised sheep in Sweden. Acta Vet Scand 2001; 42(3): 377-389. http://dx.doi. org/10.1186/1751-0147-42-377

Mederos A, Fernández S, Van Leeuwen J, Peregrine AS, Kelton D, Menzies P, et al. Prevalence and distribution of gastrointestinal nematodes on 32 organic and conventional commercial sheep farms in Ontario and Quebec, Canada (2006-2008). Vet Parasitol 2010; 170(3-4): 244-252. PMid:20236769. http://dx.doi.org/10.1016/j.vetpar.2010.02.018

O'Connor LJ, Kahn LP, Walkden-Brown SW. The effects of amount, timing and distribution of simulated rainfall on the development of Haemonchus contortus to the infective larval stage. Vet Parasitol 2007; 146(1-2): 90-101. PMid:17398009. http://dx.doi.org/10.1016/j. vetpar.2007.02.002

O'Connor LJ, Walkden-Brown SW, Kahn LP. Ecology of the freeliving stages of major trichostrongylid parasites of sheep. Vet Parasitol 2006; 142(1-2): 1-15. PMid:17011129. http://dx.doi.org/10.1016/j. vetpar.2006.08.035 
Ramos CI, Bellato V, Souza AP, Avila VS, Coutinho GC, Dalagnol CA. Epidemiologia das helmintoses gastrintestinais de ovinos no Planalto Catarinense. Ciênc Rural 2004; 34(6): 1889-1895. http://dx.doi. org/10.1590/S0103-84782004000600034

Santiago MAM, Benevenga SF, Costa UC. Epidemiologia e controle da helmintose ovina no município de Itaqui, Rio Grande do Sul. Pesq Agropec Bras 1976; 11(1): 1-7.

Santos MC, Xavier JK, Amarante MRV, Bassetto CC, Amarante AFT. Immune response to Haemonchus contortus and Haemonchus placei in sheep and its role on parasite specificity. Vet Parasitol 2014; 203(1-2): $127-$ 138. PMid:24670867. http://dx.doi.org/10.1016/j.vetpar.2014.02.048

Silva BF, Bassetto CC, Shaw RJ, Canavessi AMO, Amarante AFT. Parasitism by Oestrus ovis: Influence of sheep breed and nematode infections. Vet Parasitol 2012a; 186(3-4): 437-444. PMid:22105081. http://dx.doi.org/10.1016/j.vetpar.2011.11.007
Silva BF, Bassetto CC, Amarante AFT. Epidemiology of Oestrus ovis (Diptera: Oestridae) in sheep in Botucatu, State of São Paulo. Rev Bras Parasitol Vet 2012b; 21(4): 386-390. PMid:23295819. http://dx.doi. org/10.1590/S1984-29612012000400008

Silva MRL, Amarante MRV, Bresciani KDS, Amarante AFT. Hostspecificity and morphometrics of female Haemonchus contortus, H. placei and $H$. similis (Nematoda: Trichostrongylidae) in cattle and sheep from shared pastures in São Paulo State, Brazil. J Helminthol 2014. [Epub ahead of print]. http://dx.doi.org/10.1017/S0022149X14000078

Souza MF, Pimentel Neto M, Pinho ALS, Silva RM, Farias ACB, Guimarães MP. Seasonal distribution of gastrointestinal nematode infections in sheep in a semiarid region, northeastern Brazil. Rev Bras Parasitol Vet 2013; 22(3): 351-359. PMid:24142165. http://dx.doi. org/10.1590/S1984-29612013000300006

Ueno H, Gonçalves PC. Manual para diagnóstico das helmintoses de ruminantes. 4. ed. Tokyo: Japan International Cooperation Agency; 1998. 149 p. 